\title{
DEVELOPMENT AND VALIDATION OF A HIGH PERFORMANCE LIQUID CHROMATOGRAPHY METHOD FOR SIMULTANEOUS DETERMINATION OF GLIBENCLAMIDE AND LIPOIC ACID
}

\author{
LUMINIȚA-GEORGETA CONFEDERAT ${ }^{1 \#}$, ALEXANDRA BUJOR ${ }^{2 *}$, IUSTINA CONDURACHE ${ }^{3}$, \\ LENUT,A PROFIRE $^{4} *$, ANCA MIRON ${ }^{5}$, NELA BIBIRE $^{6}$
}

${ }^{1}$ Department of Microbiology, Faculty of Medicine, “Grigore T. Popa” University of Medicine and Pharmacy, 16 Universității Street, 700115, Iași, Romania

${ }^{2}$ Department of Pharmaceutical Technology, Faculty of Pharmacy, “Grigore T. Popa” University of Medicine and Pharmacy, 16 Universității Street, 700115, Iași, Romania

${ }^{3}$ Department of Biomedical Sciences, Faculty of Medical Bioengineering, "Grigore T. Popa” University of Medicine and Pharmacy, 16 Universității Street, 700115, Iaşi, Romania

${ }^{4}$ Department of Pharmaceutical Chemistry, Faculty of Pharmacy, "Grigore T. Popa" University of Medicine and Pharmacy, 16 Universității Street, 700115, Iași, Romania

${ }^{5}$ Department of Pharmacognosy, Faculty of Pharmacy, "Grigore T. Popa” University of Medicine and Pharmacy, 16 Universității Street, 700115, Iași, Romania

${ }^{6}$ Department of Analytical Chemistry, Faculty of Pharmacy, "Grigore T. Popa" University of Medicine and Pharmacy, 16 Universității Street, 700115, Iași, Romania

*corresponding author: lenuta.profire@umfiasi.ro

${ }^{\#}$ Authors with equal contribution.

Manuscript received: October 2020

\begin{abstract}
Glibenclamide and lipoic acid are drugs frequently co-administered in the treatment of diabetes mellitus, this association targeting the glycaemic control and the management of chronic vascular complications. Considering that literature data do not provide analytical methods for simultaneous determination of these drugs, the aim of this study was to develop and validate a new HPLC method for the achievement of this objective. The developed method allowed the efficient separation of the drugs using acetonitrile and phosphate buffer $\mathrm{pH}=2.7$ as mobile phase, with gradient elution and UV detection at 201 $\mathrm{nm}$. The method was validated, analysing the following parameters: selectivity, linearity, limit of detection and limit of quantification, precision, accuracy. All the validation parameters were within the specified limits, proving that the HPLC method was selective and linear in the defined concentration range, while the relative standard deviation for the analysis of precision and accuracy was found below $\pm 2 \%$ and $\pm 5 \%$, respectively. Moreover the method is accessible and could be applied for the simultaneous separation and quantitative determination of the associated drugs in different therapeutic systems.
\end{abstract}

\section{Rezumat}

Glibenclamidul și acidul lipoic sunt medicamente co-administrate frecvent în tratamentul diabetului zaharat, această asociere țintind controlul glicemic și managementul complicațiilor vasculare cronice. Considerând faptul că literatura de specialitate nu oferă metode analitice pentru determinarea simultană a acestor medicamente, obiectivul acestui studiu a fost dezvoltarea și validarea unei noi metode HPLC în vederea realizării acestui deziderat. Metoda dezvoltată a permis o separare eficientă utilizând ca fază mobilă acetonitril și tampon fosfat $\mathrm{pH}=2,7$, cu eluare în gradient și detecție UV la $201 \mathrm{~nm}$. Metoda a fost validată, analizând următorii parametri: selectivitatea, liniaritatea, limita de detecție și limita de cuantificare, precizia, acuratețea. Toți parametrii validării au fost în limitele specificate, dovedind faptul că metoda HPLC este selectivă și liniară pe domeniul de concentrații definit, în timp ce valoarea deviației standard relative la analiza preciziei și a acurateței a fost sub \pm $2 \%$ și $\pm 5 \%$, respectiv. Mai mult, metoda este accesibilă şi ar putea fi aplicată pentru separarea şi determinarea cantitativă simultană a substanțelor asociate din diferite sisteme terapeutice.

Keywords: glibenclamide, lipoic acid, HPLC, diabetes mellitus

\section{Introduction}

The management of diabetes mellitus is becoming more and more difficult, due to its chronic and progressive character and to the difficulty in maintaining a longterm optimal glycaemic control, being associated with the development of vascular complications as neuropathy, retinopathy, nephropathy $[2,16]$, stroke, myocardial infarction [8, 19], diabetic foot [5]. The treatment of diabetic patients is based on multiple associations of drugs, with different mechanisms of action, in order to maintain the glycaemic control and slow down the evolution of chronic complications, once appeared. 
Glibenclamide and lipoic acid are frequently coadministered to diabetic patients, this association targeting lowering blood glucose values and the management of diabetic neuropathy $[3,18]$. In addition, for lipoic acid the literature data reveals some important effects such as antioxidant $[11,17]$, increasing insulin sensitivity [10], antitumor and anti-inflammatory [9]. There are some analytical methods for the quantitative determination of each active substance. For determination of glibenclamide from pharmaceutical dosage forms, high performance liquid chromatography (HPLC) methods, using phosphate buffer:methanol $=60: 40 \%$ (v/v), $\mathrm{pH}=7$ [12] or ethanol:methanol $=50: 50 \%$ (v/v) [15], as mobile phase, with isocratic elution and UV-VIS detection, are applied. Another method using acetonitrile: water $=60: 40 \%(\mathrm{v} / \mathrm{v})$, with isocratic elution and UV-VIS detection was proposed for the determination of glibenclamide from pharmaceutical formulations and human plasma [6].

For the determination of lipoic acid from human plasma, a HPLC method using disodium hydrogenphosphate:acetonitrile:methanol = 50:30:20, with UVVIS detection was developed [7]. However, there are no analytical methods for the simultaneous determination of glibenclamide and lipoic acid, from the associated forms.

Taking these aspects into account, the aim of the present study was to develop and validate a new high performance liquid chromatography (HPLC) method, which allows the simultaneous assay of glibenclamide and lipoic acid from pharmaceutical dosage forms.

\section{Materials and Methods}

\section{Materials}

Glibenclamide (GB, min. 99\%), lipoic acid (LA, min. 98\%), LC-grade methanol, acetonitrile of chromatographic purity, ortho-phosphoric acid (min. 85\%), disodium hydrogen phosphate (min. 99\%) were purchased from Sigma Aldrich (Merck, Germany). Distilled water of chromatographic purity was purchased from Ircon (Romania).

A HPLC 1200 system (Agilent Technologies 1200, USA), equipped with a G1311A quaternary pump, G1322A degasser, Rheodyne injection loop $(20 \mu \mathrm{L})$ and a G1315B diode array detector (DAD) was used. The chromatographic column used was ODS Hypersil $\mathrm{C} 18,250 \times 4.6 \mathrm{~mm}$, the size of the particles being of $5 \mu \mathrm{m}$ (Thermo Fischer Scientific, USA).

Development and optimization of the HPLC method The development and optimization of the analytical method aimed to establish the chromatographic conditions for the separation and quantitative determination of GB and LA. The selection of chromatographic conditions was based on the literature data for the analysis of each substance separately, with modifications and optimizations for their determination from the association GB-LA $[1,7,13]$. In order to achieve this purpose, 7 methods $\left(M_{1}-M_{7}\right)$ were experimentally studied, analysing the following parameters: the composition of the mobile phase, the mobile phase gradient, the run time and the percentage of each mobile phase. The parameters of the 7 analytical methods studied are summarized in Table I.

Table I

The chromatographic parameters of the analytical methods $\left(\mathrm{M}_{1}-\mathrm{M}_{7}\right)$ studied for the development and optimization of the HPLC method

\begin{tabular}{|c|c|c|c|c|}
\hline Method & Mobile phase & Gradient & $\begin{array}{c}\text { Rate } \\
(\mathrm{mL} / \mathrm{min})\end{array}$ & $\begin{array}{c}\text { Run time } \\
(\text { min })\end{array}$ \\
\hline $\mathbf{M}_{1}$ & $\mathrm{CH}_{3} \mathrm{OH}: \mathrm{H}_{2} \mathrm{O}=85: 15, \mathrm{pH}=3.5$ & isocratic & 1 & 30 \\
\hline $\mathbf{M}_{2}$ & $\mathrm{CH}_{3} \mathrm{OH}: \mathrm{H}_{2} \mathrm{O}, \mathrm{pH}=3.5$ & $\begin{array}{c}0^{\prime}: 50 \% \mathrm{CH}_{3} \mathrm{OH} ; 5^{\prime}: 75 \% \mathrm{CH}_{3} \mathrm{OH} \\
10^{\prime}: 85 \% \mathrm{CH}_{3} \mathrm{OH} ; 15^{\prime}: 100 \% \mathrm{CH}_{3} \mathrm{OH} \\
200^{\prime}: 50 \% \mathrm{CH}_{3} \mathrm{OH}\end{array}$ & 1 & 20 \\
\hline $\mathbf{M}_{3}$ & $\mathrm{CH}_{3} \mathrm{OH}: \mathrm{H}_{2} \mathrm{O}, \mathrm{pH}=3.5$ & $\begin{array}{c}0^{\prime}: 80 \% \mathrm{CH}_{3} \mathrm{OH} ; 5^{\prime}: 85 \% \mathrm{CH}_{3} \mathrm{OH} \\
7^{\prime}: 85 \% \mathrm{CH}_{3} \mathrm{OH} ; 12^{\prime}: 90 \% \mathrm{CH}_{3} \mathrm{OH} \\
15^{\prime}: 80 \% \mathrm{CH}_{3} \mathrm{OH} \\
\end{array}$ & 1 & 15 \\
\hline $\mathbf{M}_{4}$ & $\mathrm{CH}_{3} \mathrm{OH}: \mathrm{H}_{2} \mathrm{O}, \mathrm{pH}=3.5$ & $\begin{array}{c}0^{\prime}: 80 \% \mathrm{CH}_{3} \mathrm{OH} ; 10^{\prime}: 80 \% \mathrm{CH}_{3} \mathrm{OH} \\
25^{\prime}: 85 \% \mathrm{CH}_{3} \mathrm{OH} ; 40 ’: 85 \% \mathrm{CH}_{3} \mathrm{OH} \\
50^{\prime}: 90 \% \mathrm{CH}_{3} \mathrm{OH} ; 55^{\prime}: 90 \% \mathrm{CH}_{3} \mathrm{OH} \\
60 ’: 80 \% \mathrm{CH}_{3} \mathrm{OH}\end{array}$ & 1 & 60 \\
\hline $\mathbf{M}_{5}$ & $\begin{array}{l}\text { phosphate buffer:acetonitrile: } \mathrm{CH}_{3} \mathrm{OH}= \\
50: 30: 20, \mathrm{pH}=2.7\end{array}$ & isocratic & 1 & 5 \\
\hline $\mathbf{M}_{6}$ & acetonitrile:phosphate buffer $=1: 1, \mathrm{pH}=2.7$ & isocratic & 1 & 10 \\
\hline $\mathbf{M}_{7}$ & acetonitrile:phosphate buffer, $\mathrm{pH}=2.7$ & $\begin{array}{c}0^{\prime}: 60 \% \text { PB; 5': } 60 \% \text { PB; } 25^{\prime}: 40 \% \text { PB } \\
30 ’: 40 \% \text { PB; 45': } 10 \% \text { PB; 55': 60\% PB; } \\
60 ': 60 \% \text { PB }\end{array}$ & 1 & 60 \\
\hline
\end{tabular}

Briefly, stock solutions of GB (1 mg/mL), LA (5 mg/ $\mathrm{mL})$ and a stock solution of both substances (GB 1 $\mathrm{mg} / \mathrm{mL}$ and $\mathrm{LA} 5 \mathrm{mg} / \mathrm{mL}$ ) were prepared by weighing the appropriate amount of substance and dissolving it in $50 \mathrm{~mL}$ methanol; the obtained solutions were filtered through Millipore filters $(0.22 \mu \mathrm{m})$ and injected 
in a volume of $20 \mu \mathrm{L}$. The column temperature was maintained at $25^{\circ} \mathrm{C}$. The detection was performed at different wavelengths $(201 \mathrm{~nm}, 230 \mathrm{~nm}, 245 \mathrm{~nm}, 254$ $\mathrm{nm}, 300 \mathrm{~nm}$ ), thus allowing to choose the wavelength that corresponds to the maximum absorbance peak. The chromatograms were recorded, the appearance of the peak was examined and the retention time (Rt) was calculated for each substance.

Validation of the HPLC method

After the establishment of the optimal conditions that allow the separation and quantitative determination of each substance from GB-LA association, the method was validated analysing the following parameters: selectivity, linearity, limit of detection and limit of quantification, precision, accuracy [4, 20].

Selectivity

The chromatograms of the following solutions were registered: the reference solution, represented by a stock solution containing the GB (1 mg/mL) - LA (2 $\mathrm{mg} / \mathrm{mL}$ ) association, the sample solution, represented by the solution obtained from the preparation of the therapeutic systems containing GB and LA, and the blank solution, obtained from the preparation of the therapeutic systems without GB and LA [4]. A volume of $20 \mu \mathrm{L}$ of each solution was analysed following the chromatographic conditions corresponding to $\mathrm{M}_{7}$. It were recorded the chromatograms, as well as the retention times and the shape of the peaks for each substance. The method is considered selective if the peak corresponding to GB and LA do not interfere with other peaks and has the same morphology both in the reference and in the sample solution [20]. Moreover, the selectivity factor $(\alpha)$ was calculated according to the formula:

$$
\alpha=\frac{\mathrm{Rt} 2-\mathrm{t} 0}{\mathrm{Rt} 1-\mathrm{t} 0}
$$

where $\mathrm{Rt}_{1}=$ retention time for LA in the reference solution; $\mathrm{Rt}_{2}=$ retention time for $\mathrm{GB}$ in the reference solution; $t_{0}=$ retention time of the non-retained compound on the chromatogram.

\section{Linearity}

A series of standard solutions containing the GBLA association, of known concentration, obtained by successive dilutions from a stock solution, were analysed. The concentration of standard solution ranged between 0.03125 and $1 \mathrm{mg} / \mathrm{mL}$ for GB and between 0.15625 and $5 \mathrm{mg} / \mathrm{mL}$ for LA. The chromatograms obtained for each concentration were integrated and the peak area for each substance was calculated. The linearity of the response function was determined by representing the peak area as function of concentration. Thus, the linear regression curve and its corresponding equation were obtained and further the correlation coefficient $\left(\mathrm{R}^{2}\right)$ and the standard deviation of the slope of the regression curve (SD) were calculated. From the equation of the linear regression curve the concentration was calculated, which was represented as function of the theoretical concentration. The determinations were performed in triplicate for each concentration, the peak area representing the arithmetic mean of those 3 determinations.

The calibration curve is considered linear if the correlation coefficient value $\left(\mathrm{R}^{2}\right)$ is over 0.98 [20].

Limit of detection and limit of quantification

The limit of detection (LOD), representing the minimum amount of the analyte that can be evidenced, and the limit of quantification (LOQ), representing the minimum amount of the analyte that can be quantitatively determined, were calculated based on the standard deviation (SD) and on the slope of the regression curve, using the following formulae:

$$
\begin{gathered}
\mathrm{LOD}=\frac{3.3 \times \mathrm{SD}}{\text { slope of the regression curve }} ; \\
\mathrm{LOQ}=\frac{10 \times \mathrm{SD}}{\text { slope of the regression curve }}
\end{gathered}
$$

Precision of the system (repeatability of the injection) From stock solution of GB (1 mg/mL) - LA ( $5 \mathrm{mg} / \mathrm{mL})$ association, prepared as described above, it was prepared a standard solution of GB $(0.25 \mathrm{mg} / \mathrm{mL})-$ LA $(1.25 \mathrm{mg} / \mathrm{mL})$, which was filtered and injected in volume of $20 \mu \mathrm{L}$ in the chromatographic conditions corresponding to $\mathrm{M}_{7}$. The injection was repeated for 6 times with the same solution, determining Rt and calculating the average value, standard deviation (SD) and the relative standard deviation (RSD\%). The chromatographic system used is considered precise if the RSD $\%$ is $\pm 2 \%$ [20].

Precision of the method (repeatability of the analysis) The intra-day and inter-day variations using 3 determinations for 3 levels of concentration were analysed. From the stock solution previously prepared, standard solutions for 3 levels of concentration were obtained as follows: low level $(0.0625 \mathrm{mg} / \mathrm{mL} \mathrm{GB}-$ $0.3125 \mathrm{mg} / \mathrm{mL}$ LA), medium level $(0.25 \mathrm{mg} / \mathrm{mL} \mathrm{GB}-$ $1.25 \mathrm{mg} / \mathrm{mL} \mathrm{LA})$ and high level $(0.8 \mathrm{mg} / \mathrm{mL} \mathrm{GB}-4$ $\mathrm{mg} / \mathrm{mL} \mathrm{LA}$ ). Intra-day variations: for each level of concentration, three samples were analysed, determining their experimental peak area. Inter-day variations: for each level of concentration, a sample was analysed in three different days, determining the experimental peak area. Based on the equation of the regression curve and on the peak area values, the concentrations as percent of the theoretical concentration values were determined; then the average, SD and RSD\% were calculated. The precision of the method is considered within acceptable limits if the RSD\% value is $\pm 5 \%$ [20].

\section{Signal to noise ratio}

The signal to noise ratio $(\mathrm{S} / \mathrm{N})$ was determined for each peak, corresponding to GB and to LA, respectively. This parameter was calculated using ChemStation software of HPLC apparatus, using the six times the standard deviation of the linear regression of the drift. The $\mathrm{S} / \mathrm{N}$ was calculated based on the formula:

$$
\mathrm{S} / \mathrm{N}=\frac{\text { Height of the peak }}{\text { Noise of closest range }}
$$




\section{Accuracy}

In a stock solution containing $0.25 \mathrm{mg} / \mathrm{mL} \mathrm{GB}$ and $1.25 \mathrm{mg} / \mathrm{mL} \mathrm{LA}$, determined volumes of the solution containing the substances of interest were added, in order to obtain spikes of $80 \%, 100 \%$ and $120 \%$ of the initial concentration. For each level of concentration, three samples were prepared and analysed in the mentioned conditions, determining the peak area. Based on the equation of the regression curve, the concentration of each sample and, then, the percentage of recovery, expressed as percent of the theoretical concentration, the mean recovery and RSD\% were calculated. The accuracy of the method is acceptable if $\mathrm{RSD} \%$ value is $\pm 5 \%$ [20].

\section{Results and Discussion}

Development and optimization of the HPLC method The separation of the substances is considered efficient if the Rt for GB and LA are different enough and the corresponding peaks are not overlapped, in order to allow the quantitative determination based on the peak area.

Table II

Development and optimization of the HPLC method: retention time (Rt) for GB and LA and observations for each method studied $\left(\mathrm{M}_{1}-\mathrm{M}_{7}\right)$

\begin{tabular}{|c|c|c|c|}
\hline Method & Rt LA (min) & Rt GB (min) & Observations \\
\hline $\mathbf{M}_{\mathbf{1}}$ & 5.15 & 6.19 & Partial overlap of peaks for GB and LA \\
\hline $\mathbf{M}_{\mathbf{2}}$ & - & 16.03 & Wide peak for lipoic acid \\
\hline $\mathbf{M}_{\mathbf{3}}$ & 4.55 & 5.8 & Additional peaks \\
\hline $\mathbf{M}_{\mathbf{4}}$ & 4.53 & 4.93 & Common peak for GB and LA; additional peaks \\
\hline $\mathbf{M}_{\mathbf{5}}$ & 3.4 & 3.02 & Common peak for GB and LA \\
\hline $\mathbf{M}_{\mathbf{6}}$ & - & - & Simultaneous elution of GB and LA \\
\hline $\mathbf{M}_{\mathbf{7}}$ & 9.09 & 19.05 & Individual peaks; efficient separation \\
\hline
\end{tabular}

The results (Table II) evidenced that the most efficient separation was achieved using a mixture of acetonitrile and phosphate buffer $(\mathrm{pH}=2.7)$ as mobile phase, with gradient elution, the concentration of phosphate buffer ranging between $60 \%$ and $10 \%$. Using this method $\left(\mathrm{M}_{7}\right)$, GB was able to interact more than LA with the stationary phase of the column. Consequently, individual and narrow peaks were obtained and the Rt were enough different to allow a complete separation (Rt was 19.05' for GB and 9.09' for LA). The maximum of absorption was registered at $201 \mathrm{~nm}$ for both substances, and this wavelength was chosen for all determinations.

Validation of the HPLC method

Selectivity. In order to study the selectivity of the method, the Rt values of GB and LA recorded in the chromatograms of reference solution and sample solution were compared. A maximum difference of $\pm 5 \%$ between values was accepted. The chromatograms registered for reference solution, sample solution and blank solution are presented in Figures 1, 2 and 3. The results evidenced that the Rt value for GB is 19.43' in the chromatogram of reference solution and 19.27' in that of sample solution; for LA, the Rt value is $8.84^{\prime}$ in the chromatogram of reference solution and 8.74 ' in that of sample solution; also, the chromatogram of blank solution proved no interference with the substances of interest. The calculated selectivity factor was higher than $1(\alpha=2.75)$. Based on these results, it is appreciated that the developed method is selective and allows the optimal separation of the studied substances.

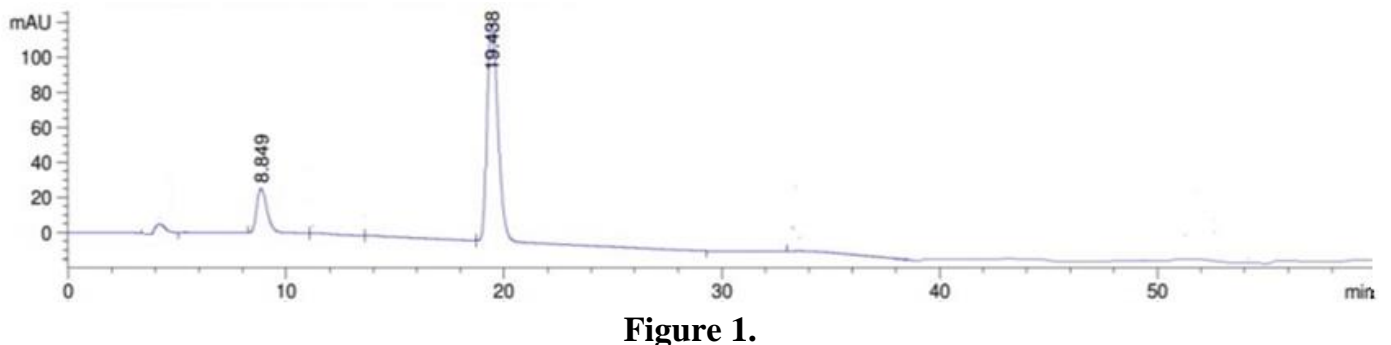

The chromatogram registered for reference solution

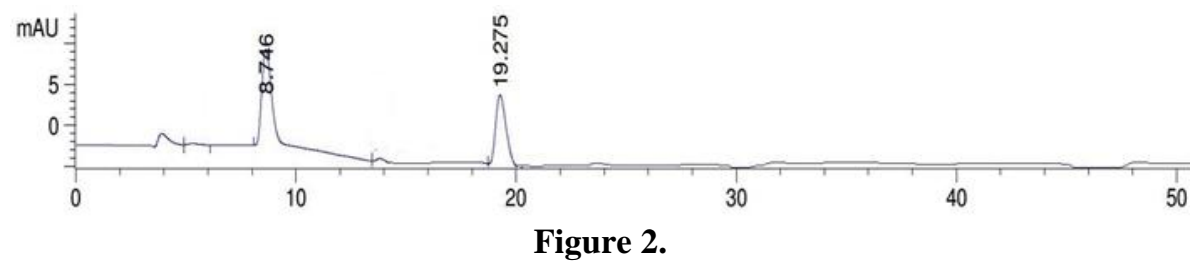

The chromatogram registered for sample of GB-LA solution 


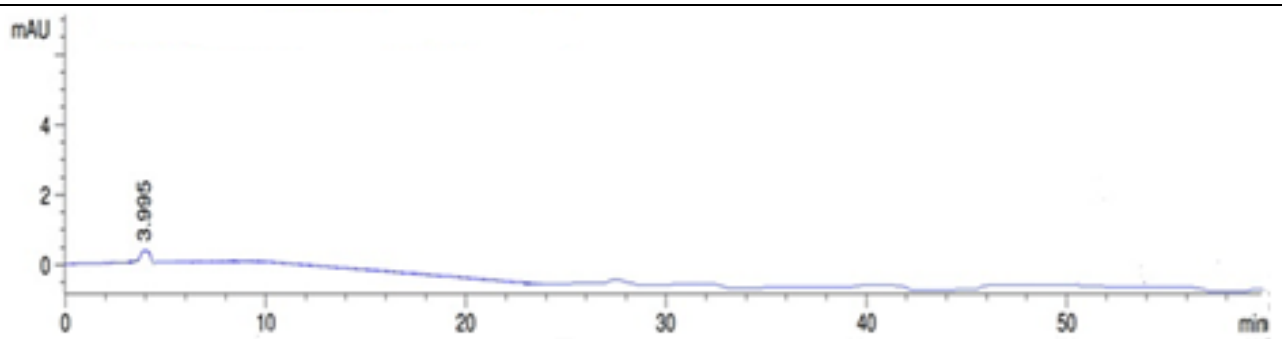

Figure 3.

The chromatogram registered for blank solution

Linearity. The linearity of the response function was obtained through the graphical representation of the mean peak area versus the concentration, drawing the calibration curve of the defined concentrations range and determining the equation of the linear regression curve and the correlation coefficient $\left(\mathrm{R}^{2}\right)$. The results prove that the linearity of the answer function is within the acceptable limits, the $R^{2}$ value being above $0.98\left(\mathrm{R}^{2}=0.9984\right.$ for $\mathrm{GB}$ and $\mathrm{R}^{2}=$ 0.9978 for LA).

The results of the linearity prove that between the theoretical concentration and the calculated concentration there is a linear correlation, the slope of the regression curve value is close to 1 ( 0.9996 for GB and 1.0001 for LA) and the intercept value is close to $0(0.0004$ for GB and 0.0001 for LA); therefore, it can be considered that the regression curve passes through origin.

Limit of detection and limit of quantification. The limit of detection and the limit of quantification have the following values: for glibenclamide, $\mathrm{LOD}=0.05$ $\mathrm{mg} / \mathrm{mL}$ and $\mathrm{LOQ}=0.16 \mathrm{mg} / \mathrm{mL}$; for lipoic acid, $\mathrm{LOD}=0.06 \mathrm{mg} / \mathrm{mL}$ and $\mathrm{LOQ}=0.18 \mathrm{mg} / \mathrm{mL}$.

Precision. The results referring to the precision of the system are presented in Table III. From the statistical analysis of the data, it can be concluded that the system is precise, the relative standard deviation (RSD\%) being below the accepted limit of $\pm 2 \%$ for both substances.

According to experimental data, the precision of the method when studying intra-day variations is within the acceptable limits, the RSD\% value being $3.56 \%$ for GB and 4\% for LA, below the accepted limit of $\pm 5 \%$ (Table IV).

Concerning inter-day variations, the precision of the method is also within the acceptable limits, the RSD\% value being $3.68 \%$ for GB and $4.16 \%$ for LA, respectively (Table V).

Table III

Precision of the system: retention time for each substance and statistical analysis

\begin{tabular}{|c|c|c|c|c|}
\hline No. det. & Rt GB (min) & Statistical data & Rt LA (min) & Statistical data \\
\hline 1 & 19.512 & \multirow{6}{*}{$\begin{array}{c}\text { Average }=19.52 \\
\mathrm{SD}=0.02 \\
\mathrm{RSD} \%=0.14 \%\end{array}$} & 8.993 & \multirow{6}{*}{$\begin{array}{c}\text { Average }=8.98 \\
\mathrm{SD}=0.02 \\
\mathrm{RSD} \%=0.27 \%\end{array}$} \\
\hline 2 & 19.577 & & 8.999 & \\
\hline 3 & 19.537 & & 9.011 & \\
\hline 4 & 19.513 & & 8.983 & \\
\hline 5 & 19.538 & & 8.949 & \\
\hline 6 & 19.497 & & 8.954 & \\
\hline
\end{tabular}

Table IV

Intra-day variations: mean recovery for each substance and statistical analysis

\begin{tabular}{|c|c|c|c|c|c|c|c|}
\hline \multirow[b]{2}{*}{$\begin{array}{l}\text { Level of } \\
\text { conc. }\end{array}$} & \multirow[b]{2}{*}{$\begin{array}{l}\text { Theoretical conc. } \\
\text { (mg/mL) }\end{array}$} & \multicolumn{3}{|c|}{ GB } & \multicolumn{3}{|c|}{ LA } \\
\hline & & $\begin{array}{c}\text { Peak } \\
\text { area } \\
(\mathbf{m U A} * \mathbf{s})\end{array}$ & $\begin{array}{c}\text { Calculated } \\
\text { conc. } \\
(\mathbf{m g} / \mathbf{m L})\end{array}$ & $\begin{array}{c}\text { Recovery } \\
(\%)\end{array}$ & $\begin{array}{c}\text { Peak area } \\
(\mathbf{m U A} * \mathbf{s})\end{array}$ & $\begin{array}{l}\text { Calculated } \\
\text { conc. } \\
(\mathrm{mg} / \mathrm{mL})\end{array}$ & $\begin{array}{c}\text { Recovery } \\
(\%)\end{array}$ \\
\hline \multirow{3}{*}{ superior } & \multirow{3}{*}{$\begin{array}{c}0.8 \mathrm{mg} / \mathrm{mL} \text { GB } \\
4 \mathrm{mg} / \mathrm{mL} \mathrm{LA}\end{array}$} & 3924.1 & 0.82 & 102.5 & 1995.5 & 3.92 & 98 \\
\hline & & 4378.7 & 0.90 & 112.5 & 2162 & 4.25 & 106.2 \\
\hline & & 3835.2 & 0.803 & 100.3 & 2051.7 & 4.03 & 100.7 \\
\hline \multirow{3}{*}{ medium } & \multirow{3}{*}{$\begin{array}{l}0.25 \mathrm{mg} / \mathrm{mL} \mathrm{GB} \\
1.25 \mathrm{mg} / \mathrm{mL} \mathrm{LA}\end{array}$} & 1273.8 & 0.260 & 104 & 633.7 & 1.226 & 98.08 \\
\hline & & 1265.1 & 0.258 & 103.2 & 635.1 & 1.223 & 97.84 \\
\hline & & 1235.8 & 0.252 & 100.8 & 601.3 & 1.156 & 92.48 \\
\hline \multirow{3}{*}{ inferior } & \multirow{3}{*}{$\begin{array}{l}0.0625 \mathrm{mg} / \mathrm{mL} \mathrm{GB} \\
0.3125 \mathrm{mg} / \mathrm{mL} \mathrm{LA}\end{array}$} & 341.2 & 0.063 & 100.8 & 177.9 & 0.317 & 101.44 \\
\hline & & 346.3 & 0.064 & 102.4 & 180.7 & 0.322 & 103.04 \\
\hline & & 353.6 & 0.065 & 104 & 180.5 & 0.322 & 103.04 \\
\hline \multicolumn{2}{|c|}{ Statistical data } & \multicolumn{3}{|c|}{$\begin{array}{c}\text { Mean recovery }=103.38 \% \\
\mathrm{SD}=3.68 \\
\mathrm{RSD} \%=3.56 \%\end{array}$} & \multicolumn{3}{|c|}{$\begin{array}{c}\text { Mean recovery }=100.09 \% \\
\mathrm{SD}=4.00 \\
\mathrm{RSD} \%=4 \%\end{array}$} \\
\hline
\end{tabular}


Inter-day variations: mean recovery for each substance and statistical analysis

\begin{tabular}{|c|c|c|c|c|c|c|c|}
\hline \multirow[b]{2}{*}{$\begin{array}{l}\text { Level of } \\
\text { conc. }\end{array}$} & \multirow[b]{2}{*}{$\begin{array}{l}\text { Theoretical conc. } \\
\qquad(\mathrm{mg} / \mathrm{mL})\end{array}$} & \multicolumn{3}{|c|}{ GB } & \multicolumn{3}{|c|}{ LA } \\
\hline & & $\begin{array}{c}\text { Peak area } \\
(\mathbf{m U A} * \mathbf{s})\end{array}$ & $\begin{array}{l}\text { Calculated } \\
\text { conc. } \\
(\mathbf{m g} / \mathbf{m L})\end{array}$ & $\begin{array}{c}\text { Recovery } \\
(\%)\end{array}$ & $\begin{array}{c}\text { Peak area } \\
\left(\mathbf{m U A}{ }^{*} \mathbf{s}\right)\end{array}$ & $\begin{array}{c}\text { Calculated } \\
\text { conc. } \\
(\mathbf{m g} / \mathbf{m L})\end{array}$ & $\begin{array}{c}\text { Recovery } \\
(\%)\end{array}$ \\
\hline \multirow{3}{*}{ superior } & \multirow{3}{*}{$\begin{array}{c}0.8 \mathrm{mg} / \mathrm{mL} \mathrm{GB} \\
4 \mathrm{mg} / \mathrm{mL} \mathrm{LA}\end{array}$} & 3829.9 & 0.802 & 100.2 & 2002.33 & 3.93 & 98.25 \\
\hline & & 3755.63 & 0.786 & 98.25 & 2013.66 & 3.95 & 98.75 \\
\hline & & 3811.81 & 0.798 & 99.85 & 2045.11 & 4.01 & 100.47 \\
\hline \multirow{3}{*}{ medium } & \multirow{3}{*}{$\begin{array}{l}0.25 \mathrm{mg} / \mathrm{mL} \mathrm{GB} \\
1.25 \mathrm{mg} / \mathrm{mL} \mathrm{LA}\end{array}$} & 1194.47 & 0.243 & 97.2 & 629.61 & 1.21 & 96.8 \\
\hline & & 1239.88 & 0.253 & 101.2 & 646.73 & 1.246 & 99.68 \\
\hline & & 1208.77 & 0.247 & 98.8 & 614.27 & 1.181 & 94.56 \\
\hline \multirow{3}{*}{ inferior } & \multirow{3}{*}{$\begin{array}{l}0.0625 \mathrm{mg} / \mathrm{mL} \text { GB } \\
0.3125 \mathrm{mg} / \mathrm{mL} \text { LA }\end{array}$} & 357.6 & 0.067 & 107.6 & 180.69 & 0.322 & 104.4 \\
\hline & & 341.45 & 0.063 & 100.8 & 189.92 & 0.341 & 109.1 \\
\hline & & 356.97 & 0.067 & 107.2 & 175.46 & 0.312 & 99.84 \\
\hline \multicolumn{2}{|c|}{ Statistical data } & \multicolumn{3}{|c|}{$\begin{array}{c}\text { Mean recovery }=101.24 \% \\
\mathrm{SD}=3.73 \\
\mathrm{RSD} \%=3.68 \%\end{array}$} & \multicolumn{3}{|c|}{$\begin{array}{c}\text { Mean recovery }=100.094 \% \\
\mathrm{SD}=4.16 \\
\mathrm{RSD} \%=4.16 \%\end{array}$} \\
\hline
\end{tabular}

Signal to noise ratio $(S / N)$. The $\mathrm{S} / \mathrm{N}$ value for $\mathrm{GB}$ was 584.5 (time range for noise calculation 17.5 $18.5 \mathrm{~min}$ ) and 529.8 (time range 7 - $8 \mathrm{~min}$ ). For LA, the $\mathrm{S} / \mathrm{N}$ value was 315.5 (time range $7-8 \mathrm{~min}$ ) and 348.2 (time range $17.5-18.5 \mathrm{~min}$ ). The $\mathrm{S} / \mathrm{N}$ values determined are above 50, the limit considered to provide an acceptable precision of the HPLC methods [14]. Accuracy. Accuracy is an important parameter that reflects the approximation of the experimental results with the real ones, measuring the deviation from the real value of the average value obtained following the experimental analysis [7]. The results (Table VI) prove that the accuracy of the HPLC method is within the acceptable limits; the mean recovery was $102.32 \%$ for GB and $94.27 \%$ for LA, the RSD\% value being below $\pm 5 \%$ for both substances.

This developed and validated HPLC method was applied for the simultaneous determination of GB and LA from new pharmaceutical systems, type chitosanGB-LA microparticles, obtained through ionic gelation method. Using this method the encapsulation efficiency and drug release from the polymeric matrix were determined.

The mean recovery for each substance and statistical analysi

\begin{tabular}{|c|c|c|c|c|c|c|c|c|}
\hline \multirow[b]{2}{*}{$\begin{array}{l}\text { Level } \\
\text { of } \\
\text { conc. }\end{array}$} & \multicolumn{4}{|c|}{ GB } & \multicolumn{4}{|c|}{ LA } \\
\hline & $\begin{array}{c}\text { Theoretical } \\
\text { conc. } \\
(\mathrm{mg} / \mathrm{mL})\end{array}$ & $\begin{array}{c}\text { Peak } \\
\text { area } \\
\left(\mathbf{m U A} \mathbf{A}^{*} \mathbf{s}\right) \\
\end{array}$ & $\begin{array}{c}\text { Calculated } \\
\text { conc. } \\
(\mathbf{m g} / \mathbf{m L})\end{array}$ & $\begin{array}{c}\text { Recovery } \\
(\%)\end{array}$ & $\begin{array}{c}\text { Theoretical } \\
\text { conc. } \\
(\mathrm{mg} / \mathrm{mL})\end{array}$ & $\begin{array}{c}\text { Peak } \\
\text { area } \\
(\mathbf{m U A} * \mathbf{s}) \\
\end{array}$ & $\begin{array}{c}\text { Calculated } \\
\text { conc. } \\
(\mathrm{mg} / \mathrm{mL})\end{array}$ & $\begin{array}{c}\text { Recovery } \\
(\%)\end{array}$ \\
\hline \multirow{3}{*}{$80 \%$} & \multirow{3}{*}{0.2} & 1045.4 & 0.212 & 106.10 & \multirow{3}{*}{1} & 508.4 & 0.972 & 97.25 \\
\hline & & 1051.8 & 0.213 & 106.87 & & 509.1 & 0.970 & 97.39 \\
\hline & & 1042.3 & 0.211 & 105.86 & & 509.5 & 0.974 & 97.4 \\
\hline \multirow{3}{*}{$100 \%$} & \multirow{3}{*}{0.25} & 1235.3 & 0.252 & 100.80 & \multirow{3}{*}{1.25} & 604.1 & 1.162 & 92.98 \\
\hline & & 1239.8 & 0.253 & 101.43 & & 607.7 & 1.169 & 93.55 \\
\hline & & 1234.5 & 0.252 & 100.80 & & 605.3 & 1.164 & 93.17 \\
\hline \multirow{3}{*}{$120 \%$} & \multirow{3}{*}{0.3} & 1453.5 & 0.298 & 99.63 & \multirow{3}{*}{1.5} & 715.2 & 1.382 & 92.17 \\
\hline & & 1474.2 & 0.303 & 101.09 & & 712.4 & 1.377 & 91.80 \\
\hline & & 1434.9 & 0.294 & 98.31 & & 719.9 & 1.391 & 92.79 \\
\hline \multicolumn{2}{|c|}{ Statistical data } & \multicolumn{3}{|c|}{$\begin{array}{c}\text { Mean recovery }=102.32 \% \\
\mathrm{SD}=3.11 \\
\mathrm{RSD} \%=3.04 \%\end{array}$} & & \multicolumn{3}{|c|}{$\begin{array}{c}\text { Mean recovery }=94.27 \% \\
\mathrm{SD}=2.35 \\
\mathrm{RSD} \%=2.50 \%\end{array}$} \\
\hline
\end{tabular}

\section{Conclusions}

The present study proposed a new simple, selective, accurate and precise HPLC method for the simultaneous quantitative determination of glibenclamide (GB) and lipoic acid (LP). This method could be recommended for efficient routine assays that allow the determination of these substances associated in multi-component dosage formulations such as microparticles based on chitosan.

\section{Acknowledgement}

This research activity was financially supported by L'Oréal-UNESCO through the fellowship program "For women in science" and the grant of UEFISCDI, PN III Program, AUF-RO, AUF-IFA 2019-2020, contract no. $28 / 2019$.

\section{Conflict of interest}

The authors declare no conflict of interest. 


\section{References}

1. Aher A, Jain HK, Development and Validation of RP-HPLC method for estimation of Gliclazide in bulk and tablet dosage form. Am J Pharm Tech Res., 2015; 5(3): 658-667.

2. Avogaro A, Fadini GP, Microvascular complications in diabetes: A growing concern for cardiologists. Int J Cardiol., 2019; 291: 29-35.

3. Baynest HW, Classification, pathophysiology, diagnosis and management of diabetes mellitus. $J$ Diabetes Metab., 2015; 6(5): 541: 1-9.

4. Bibire N, Vieriu M, Panainte AD, Agoroaei L, Uncu L, Vlase CV, Vlase A, A new high performance liquid chromatographic analysis method for ciprofloxacine. Rev Chim., 2015; 66(9): 1463-1466.

5. Dewi F, Hinchliffe RJ, Foot complications in patients with diabetes. Surgery, 2019; 37(2): 106-111.

6. El-Adl SM, El-Sadek ME, Hasan MH, Design and validation of stability assay of glibenclamide using RT-HPLC technique in both bulk, pharmaceutical formulations and human plasma. J App Pharm., 2017; 9(4): 250: 1-6.

7. Ezhilarasi K, Sudha V, Ramachandran G, Umapathy D, Rajaram R, Padmalayam I, Viswanathan V, Hemanth Kumar AK, A simple and specific method for estimation of lipoic acid in human plasma by high performance liquid chromatography. J Chromatog Separat Techniq., 2014; 5(6): 245: 1-5.

8. Fisher M, Macrovascular disease in diabetes. Medicine, 2006; 34(3): 101-103.

9. Golbidi S, Badran M, Laher I, Diabetes and alpha lipoic acid. Front Pharmacol., 2011; 2: 69: 1-15.

10. Gomes MB, Negrato CA, Alpha-lipoic acid as a pleiotropic compound with potential therapeutic use in diabetes and other chronic diseases. Diabetol Metab Syndr., 2014; 6: 80: 1-18.
11. Gorąca A, Huk-Kolega H, Piechota A, Kleniewska P, Ciejka E, Skibska B, Lipoic acid - biological activity and therapeutic potential. Pharmacol Rep., 2011; 63(4): 849-858.

12. Harika KSL, Ravindra RY, Shamitha SR, Shiva T, Sandeep T, Rama SR, Estimation of glibenclamide present in tablets by RP-HPLC. Int $J$ Pharm Technol., 2010; 2(4): 1105-1117.

13. Imre $\mathrm{S}, \mathrm{Al}$ Hussein $\mathrm{SM}$, Pascu A, Oltean (Gliga) LE, Dogaru MT, Al Hussein H, Muntean DL, TeroVescan A, Concomitant HPLC analysis of adapalene and nadifloxacin in the presence of glycolic acid. Farmacia, 2019; 67(6): 948-954.

14. Meyer C, Seiler P, Bies C, Cianciulli C, Wätzig H, Meyer VR, Minimum required signal-to-noise ratio for optimal precision in HPLC and CE. Electrophoresis, 2012; 33(11): 1509-1516.

15. Nazrul H, Fars KA, Ibrahim AA, Faiyaz S, Rapid analysis of glibenclamide using an environmentally benign stability-indicating RP-HPLC method. IJPR., 2014; 13(3): 863-872.

16. Pickett KA, Microvascular Complications of Diabetes: What's Relevant for Practice?. J Nurse Pract., 2016; 12(10): 683-690.

17. Shay KP, Moreau R, Smith EJ, Smith AR, Hagen TM, Alpha-lipoic acid as a dietary supplement: Molecular mechanisms and therapeutic potential. Biochim Biophys Acta., 2009; 1790(10): 1149-1160.

18. Thulé PM, Umpierrez G, Sulfonylureas: a new look at old therapy. Curr Diab Rep., 2014; 14(4): 473: 1-8.

19. Vella S, Petrie JR, Macrovascular disease: pathogenesis and risk assessment. Medicine, 2015; 43(1): 1-6.

20. *** Analytical Procedures and Methods Validation for Drug and Biologics - Guidance for Industry, 2015. 